\title{
ENSURING THE WELL-BEING OF THE ELDERLY: REVISITING THE ROLE AND ADEQUACY OF SOCIAL PROTECTION SCHEMES IN MALAYSIA AND THE PHILIPPINES
}

\author{
Mohammad Abu Taher \\ Dept. of Law \& Justice, Southeast University, Dhaka \\ E-mail: taherlaw16@gmail.com (corresponding author)
}

Siti Zaharah Jamaluddin

Faculty of Law, Multimedia University, Malaysia

E-mail:sz12789@gmail.com

Jal Zabdi Mohd. Yusoff

Faculty of Law, University of Malaya,

Kuala Lumpur

E-mail: jalzabdi@um.edu.my

Zulazhar Tahir

Faculty of Law, University of Malaya,

Kuala Lumpur

E-mail: zulazhar@um.edu.my

Sridevi Thambapillay

Faculty of Law, University of Malaya,

Kuala Lumpur

E-mail: sridevit@um.edu.my

Abstract: Globally, social protection schemes are considered as effective tools in ensuring the well-being of the poor, disempowered and otherwise marginalised people of society. It is applicable in cases of elderly people who are comparatively vulnerable due to their old age, and at times poverty or the lack of financial security. The proportion of elderly people in poverty is higher than that in the working age population, indicating the increasing likelihood of people falling into poverty as they leave or retire from the workforce. Therefore, one way of addressing poverty among the elderly is through 
social protection mechanisms. Malaysia and the Philippines are two Southeast Asian countries on their way to becoming ageing nations. As such, both these countries have already adopted numerous social protection schemes to ensure the well-being of the marginalised segments of society, including the elderly. Thus, based on existing literature, this paper is an attempt to revisit and re-examine the role and adequacy of existing social protection schemes available in Malaysia and the Philippines.

Keywords: Employees Provident fund, Pension scheme, Social protection, Well-being of Elderly People

Abstrak: Pada peringkat global, skim perlindungan sosial dianggap sebagai satu mekanisme yang berkenaan untuk memastikan kesejahteraan mereka yang miskin, tidak berdaya dan yang mereka yang terpinggir. Ini termasuklah kes yang melibatkan warga tua yang juga terdedah kepada bahaya kerana faktor usia, kemiskinan ataupun kekangan dalam bentuk jaminan kewangan. Kadar kemiskinan yang melibatkan warga tua adalah lebih tinggi daripada mereka yang dalam kumpulan yang sedang bekerja. Ini menunjukkan peningkatan kebarangkalian seseorang itu termasuk ke dalam kategori miskin apabila mereka berhenti dari bekerja atau bersara. Oleh itu, salah satu cara untuk menangani isu kemiskinan di kalangan warga tua adalah menerusi mekanisme pelindungan sosial. Malaysia dan Filipina merupakan dua buah negara di Asia Tenggara yang sedang menuju ke arah Negara Tua. Oleh itu, kedua-dua negara telah melaksanakan beberapa skim perlindungan sosial untuk memastikan kesejahteraan kumpulan yang terpinggir dalam masyarakat termasuklah warga tua. Sehubungan dengan itu, berdasarkan literatur sedia ada, kertas penyelidikan ini akan melihat dan meneliti semula peranan dan kecukupan skim perlindungan sosial yang sedia ada di Malaysia dan Filipina.

Kata Kunci: Kumpulan Wang Simpanan Pekerja, Skim Pencen, Perlindungan Sosial, Kesejahteraan Warga Emas

\section{INTRODUCTION}

The global population has been experiencing significant ageing a process that results in rising proportions of elderly people in the 
total population since the mid-twentieth century. ${ }^{1}$ Ageing had started earlier in the more developed regions and in some developing countries and later became more evident on a global scale around the time of the International Conference on Population and Development in Cairo, Egypt in 1994. It was further advanced during the Second World Assembly on Ageing, which took place in Madrid, Spain, in 2002 , and the demographic projections at that time evidenced an unmistakeable trend in continued ageing, which would no doubt consolidate in the 21 st century. ${ }^{2}$

All societies throughout the world, whether developing or developed, are not free from the trend of ageing populations. In the past, the growth of elderly people was exclusively a problem faced by the more developed countries. However, the structural change in the global population is further complicated by the accelerated rate of ageing in the less developed societies that are taking a shorter time to make the demographic transition. In fact, since 1955, the rate of ageing in the developing countries increased to almost three times that of the developed regions. Many third world countries are ageing faster at lower development levels and there is less time for developing nations to adjust and react to the rapid transition in their population. The United Nations mentioned in their report on World Population Ageing: 1950 - 2050 that:

The developing countries will also reach that stage [same percentage of persons aged 60 years and above as the more developed regions have encountered in 2000] over a much shorter period of time than that required by the more developed regions. In many cases, rapid population ageing will be taking place in countries where the level of economic development is still low. ${ }^{3}$

Like other developing countries in the world, Malaysia is on its way to becoming an ageing nation. Factors such as longer life expectancy,

This study was supported by the 'Protecting Elderly Against Abuse \& Neglect: A Legal Strategy (PEACE)', a project initiated by the University of Malaya/ Ministry of Higher Education (UM/MOHE) research grant GC001E-14HTM The United Nations, World Population Ageing 2013.

Ibid.

The United Nations Population Division, The World Population Ageing: 19502050, New York, 2001, http://www.un.org/esa/population/publications/worldageing19502050/pdf/92chaptervi.pdf, (Last visited on June 29, 2015). 
escalation of health level, low mortality as well as declining fertility has brought about a change in the demographic profile of Malaysia's population. By the year 2030, Malaysia is expected to attain 'Ageing Nation Status' with elderly people ${ }^{4}$ constituting $15 \%$ of the total population. ${ }^{5}$ This alarming fact has prompted the Malaysian government to search for better solutions to overcome the challenge of providing social protection ${ }^{6}$ for the elderly in the years ahead. On the other hand, in the Philippines, another Southeast Asian country, the number of elderly people is also increasing rapidly, faster than growth in the total population. ${ }^{7}$ In 2000 , there were 4.6 million elderly people (60 years or older), accounting for $5.97 \%$ of the total population. ${ }^{8}$ In one decade, this grew to 6.5 million older people or about $6.9 \%$ of the total population. The National Statistics Office projects that by 2030 , older people will make up around 11.5 $\%$ of the total population and by 2040 the Philippines will be an ageing nation where the number of elderly people will be more than $15 \%$ of the total population. ${ }^{9}$ This increasing number of the elderly population has forced the Philippines government to adopt a number of strategies to address issues of the elderly. Like Malaysia, social protection schemes in the Philippines have been undertaken to ensure the well-being of the elderly. However, are these social protection schemes adequate to ensure the well-being of elders? Do these social protection schemes actually play an effective role in

$4 \quad$ In Malaysia, the National Policy for the Elderly 1995 defines the elderly as those who are 60 years old and above. This definition is based on that made at the World Assembly on Aging in Vienna in 1982.

5 Siti Zaharah Jamaluddin, Gan Ching Chuang, and Mohammad Abu Taher, Strategies in the Prevention or Reduction of Elder Abuse in Bangladesh and Malaysia, 172 Procedia-Social and Behavioral Sciences, 43 (2015).

6 "Social safety net" and "social security" are sometimes used as an alternative to "social protection." Of the three terms, "social protection" is the term most commonly used internationally. The term "social safety net" appears to have a less precise meaning; some people use it to mean the whole set of programmes and policies discussed in this strategy, others use it to refer only to welfare programmes targeted at the poor. On the other hand, the term "social security" is generally used to refer to the comprehensive mechanisms and coverage in high-income countries, and is less applicable to new areas such as community and area-based schemes.

7 HelpAge International, Ageing population in the Philippines, http://ageingasia. org/ageing-population-philippines1/ (accessed on June 29, 2015).

8 Sanchez, N. K., 'The Filipino Senior Citizen: at a Glance' (2008) ISA RC11 Sociology of Aging 4.

$9 \quad$ Ibid. 
ensuring the well-being of the elderly? To seek answers to these questions, it is indeed timely to examine the role and adequacy of existing social protection schemes to ensure the well-being ${ }^{10}$ of the elderly in these two Southeast Asian countries (Malaysia and the Philippines). ${ }^{11}$

In this paper, focus will be placed on the integral element of social protection schemes e.g. pension, the Employees Provident Fund (EPF), etc. It will first highlight the concept of social protection. Then the existing social protection schemes both in Malaysia and the Philippines will be discussed. Concentration will be placed on the adequacy of social protection in both countries. It will further analyse how social protection schemes can play an effective role in ensuring the well-being of the elderly. The analysis will proceed to argue that as a solution, the countries should adopt a comprehensive social protection scheme including an implementation mechanism in order to ensure the well-being of the elderly.

\section{CONCEPT OF SOCIAL PROTECTION}

Generally, social protection is a major arena of government activity to ensure that vulnerable groups of people receive appropriate and effective public support to protect their financial security and to safeguard their health. ${ }^{12}$ As such, the term 'social protection' indicates a wide meaning, signifying a full range of transfers (in cash and in kind) for protective objectives, services and also institutional safeguards to protect the population who are at risk of being in need..$^{13}$ According to Devereux and Sabates-Wheeler,

10 To ensure well-being means the process of optimising opportunities for health, participation and security in order to enhance quality of life as people age.

11 As the founding members of ASEAN both countries have some common features. For example, the majority of the people of these countries are of Austronesian (Malayo-Polynesian) ancestry. The Malay and Filipino language share the same words. Both lay claim to the state of Sabah and Borneo. Even though the elderly population is not a serious concern, the number of ageing people is increasing in both countries.

12 David E. Bloom, Emmanuel Jimenez, and Larry Rosenberg, "Social Protection of Older People", Working Paper Series, 2011, Program on the Global Demography of Aging, p.1.

13 Guy Standing, 'Social Protection' (2007) 17 (4/5) Development in Practice 512. 
Social protection describes all public and private initiatives that provide income and consumption transfers to the poor, protect the vulnerable against livelihood risks, and enhance the social status and rights of the marginalised; with the overall objective of reducing the economic and social vulnerability of the poor, vulnerable and marginalised groups. ${ }^{14}$

International organisations like the Asian Development Bank (ADB) and the World Bank (WB) have provided a more workable definition of social protection. The organisations view social protection as public action or public measures towards various risks and eventualities. ${ }^{15}$ According to the WB, social protection means "public interventions to assist individuals, households and communities to manage risks better and that provide support to the critically poor."16 The ADB regards social protection "as the set of policies and programmes designed to reduce poverty and vulnerability by promoting efficient labour markets, diminishing people's exposure to risks, and enhancing their capacity to protect themselves against hazards and interruption/loss of income." 17 However, while the ADB's framework has the mechanisms and instruments to cover the poor and vulnerable, the WB offers a matrix of social protection to cover the elderly. It is comprehensive, all-encompassing and yet typifies the different mechanisms to study social protection for the aged. ${ }^{18}$

On the whole, it can be said that the social protection schemes are policies and actions which enhance capacities and opportunities for the poor and vulnerable to improve and sustain their livelihoods and welfare in a manner that guarantees a minimum level of well-being,

14 Devereux, S. and R. Sabates-Wheeler. 2004. Transformative Social Protection. Vol. 232. University of Sussex, Institute of Development Studies.

15 Helmut Spitzer, Hossea Rwegoshora, and Zena Mnasi Mabeyo, The (Missing) Social Protection for Older People in Tanzania, Final Report, 2009, Institute of Social Work, Tanzania.

16 Robert Holzmann and Steen Jorgensen, Social Risk Management: A New conceptual framework for social protection, and beyond, Social Protection Discussion Paper No. 0006, World Bank, February 2000, p.3.

17 Asian Development Bank, Social Protection, 2003, p.1.

18 Philomena Makena Mathiu and Elosy Kangai Mathiu, 'Social protection for the elderly as a development strategy: A case study of Kenya's old persons cash transfer programme', III IESE Conference "Mozambique: Accumulation and Transformation in a Context of International Crisis," 4-5 September 2012. 
including access to food, health care, and housing, etc. ${ }^{19}$ The full range of social protection interventions can be categorised under protective, preventive, promotive and transformative measures as follows:

\section{Protective Measures}

Protective measures provide relief from deprivation. Protective measures are narrowly targeted safety net measures in the conventional sense - they aim to provide relief from poverty and deprivation largely because promotional and preventive measures have failed to do so. Protective measures include social assistance for the "chronically poor", especially those who are unable to work and earn their livelihood. Generally, social assistance schemes comprise programmes designed to help the most vulnerable individuals (i.e., those with no other means of support such as single parent households, old age people, handicapped people, or the destitute poor), households and communities to meet a social floor and improve living standards. These programmes consist of all forms of public action, government and non-government, that are designed to transfer resources, either, in cash or in kind (e.g. food transfers), to eligible, vulnerable and deprived persons. This equates most closely to mainstream "social welfare". Social assistance programmes typically include targeted resource transfers - disability benefits, single parent allowances, and "social pensions" for the elderly poor that are financed publicly - out of the tax base, with donor support, and/or through projects of non-governmental organisations (NGOs). Other protective measures can be classified as social services. These would be for the poor and groups needing special care and support. ${ }^{20}$

\section{Preventive Measures}

Preventive measures seek to avert deprivation. Preventive measures deal directly with poverty alleviation. They include social insurance for "economically vulnerable groups" - people who have fallen or might fall into poverty, and may need support to help them manage their livelihood shocks. Social insurance schemes are contributory programmes that protect beneficiaries from catastrophic expenses

\footnotetext{
19 Ibid.

20 Devereux and Sabates-Wheeler, supra note 14 at p.10.
} 
in exchange for regular payments of premiums. This is similar to "social safety nets". Social insurance programmes refer to formalised systems of pensions, health insurance, maternity benefits and unemployment benefits, often with tripartite financing between employers, employees and the state. They also include informal mechanisms, such as savings clubs and funeral societies.

\section{Promotive Measures}

Promotive measures aim to enhance real incomes and capabilities, which is achieved through a range of livelihood-enhancing

programmestargeted athouseholds and individuals, e.g. microfinance. The inclusion of promotive measures as a category here is open to criticism that it takes social protection too far beyond its original conceptualisation. However, the intention is not to broaden the scope to include (potentially) all development initiatives, but to focus on promotive measures that have income stabilisation at least as one of its objectives. A case in point is microcredit that fulfils income stabilising and consumption smoothing functions.

\section{Transformative Measures}

Transformative measures seek to address concerns of social equity and exclusion, such as collective action for workers' rights, or upholding human rights for minority ethnic groups. Transformative interventions include changes to the regulatory framework to protect "socially vulnerable groups" (e.g. people with disabilities, old age people) against discrimination and abuse. ${ }^{21}$

\section{SOCIAL PROTECTION FOR THE ELDERLY IN MALAYSIA}

In Malaysia, formal social protection includes the government pension scheme, the Employees Provident Fund (EPF) established in 1951 and the Social Security Organisation (SOCSO), established in 1969. Besides the EPF, for those in the private sector, there is a private retirement fund (PRS) established in 2012. There is also a Social Assistance Scheme provided by the Social Welfare Department for the destitute elderly. These schemes provide protection for different

21 Ibid. 
exigencies such as disability as in the case of SOCSO, old age (pensions and the EPF) and death. ${ }^{22}$

\section{Pension Scheme}

The pension system was developed in the 20th century, universally, to encourage exit from the working world and to manage the cost of retirement. ${ }^{23}$ At the beginning of the 21 st century, however, working through a ripe old age is both possible and desirable. Thus, policy changes are necessary for the elderly to fulfil the purposes of later life in society, which include leading dignified and secured lives and being treated equally with younger people so as to enable the elderly to continuously develop themselves. ${ }^{24}$

In Malaysia, the pension scheme is established under the Pensions Act $1980 .{ }^{25}$ It is a non-contributory social protection scheme specifically for government employees. It is one of the largest and the earliest protection schemes for old age in Malaysia provided by the government under the Public Services Department (PSD). ${ }^{26}$ The expenditure for pensions is wholly borne by the Federal Government ${ }^{27}$ through annual allocations from the Federal Budget. An employee who has served at least 10 years is entitled to receive a life-long monthly pension upon retirement. ${ }^{28}$ The quantum receivable by an employee who has completed at least 25 years of service is half of the last drawn salary. ${ }^{29}$ Other benefits offered in

\footnotetext{
22 Fon Sim Ong, David R. Phillips, and Tengku Azian Hamid, 'Ageing in Malaysia: Progress and prospects', in Ageing in East Asia: Challenges and policies for the twenty-first century by Tsung- hsi Fu and Rhidian Hughes eds. (Routledge: London \& New York, 2009), p. 145.

23 Sanyal, A., \& Singh, C., 'Universal Pension Scheme in India' (2013) 420 IIM Bangalore Research Paper, p.4.

24 HelpAge International, Strengthening Older People's Rights: Towards a UN Convention (2010), p.5.

25 To provide for the administration of pensions, gratuities and other benefits for officers in the public service and their dependants, the Pensions Act 1980 was passed in the Parliament. After the Royal Assent in 11th February 1980, the Act was published in the gazette notification on 28th February 1980. Even though the Act was enacted in 1980, the Act has been given a retrospective effect as it came into force from 1st January 1976.

26 Samad, S. A. and Norma Mansor, Population Ageing and Social Protection in Malaysia, 50 (2) Malaysian Journal of Economic Studies, 144 (2013).

27 Section 4 of the Act 1980.

28 Section $8($ b) of the Act 1980.

29 See, sections 22-22A of the Act 1980.
} 
the pension scheme include service pension and service gratuity which is a lump sum payment granted to a pensionable officer upon retirement. This scheme serves not only as security for old age, it is designed to provide financial assistance to the dependents of those in the government service in the form of derivative pension in the event that the government employee passes away while in service or after retirement. ${ }^{30}$ It is also a safety net for officers who are forced to retire or pass away due to injuries or sickness in the course of performing their official duties. ${ }^{31}$

\section{Employees Provident Fund (EPF)}

The Ministry of Finance established the EPF to provide social protection coverage to all employees in the private sector regardless of their status. Government sector employees who opt for the EPF will come under this scheme. ${ }^{32}$ It is considered a Trust Fund created under the EPF Ordinance 1951 and currently operates under the Employees Provident Fund Act 1991, amended in 1995. ${ }^{33}$ It is a defined contribution plan to cater for the non-pensionable workforce based on a prescribed rate of contribution by employers and employees i.e. $12 \%$ and $11 \%$ for employers and employees, respectively. ${ }^{34}$

The EPF fund is maintained in two accounts i.e. Account I and Account II, and contributors can withdraw their contribution upon retirement at the age of $55 .{ }^{35}$ Moreover, it is possible to withdraw the contribution once a contributor is incapacitated, decides to leave the country, makes an investment or is deceased. ${ }^{36}$ The second account

30 Sections $14-15$ of the Act 1980.

31 Sections $17-18$ of the Act 1980.

33 For providing a scheme of savings for employees' retirement and the management of savings for retirement purposes, the Employees Provident Fund Act was enacted in 1991 which came into effect from 1 June 1991.

34 Section 43 (1) of the Act 1991.

35 It is still unchanged even though the retirement age is now 60 .

36 Mansor, N., T.E. Chye, A. Boerhanoeddin, F. Said and S.M. Said, (2001). 'Malaysia: Protecting workers and fostering growth', in East Asian Labor Markets and the Economic Crisis: Impacts Responses and Lessons, by G. Betcherman and R. Islam eds. (United States of America: World Bank Publications, 2001), pp.141-194. 
(Account II) is, however, considered in preparation for a comfortable retirement after attaining the age of 50 years. Contribution can be withdrawn to purchase and/or build a house, reduce/redeem a housing loan, finance the education of contributors' children, pay for medical expenses of contributors and that of their children, and perform the haj. ${ }^{37}$

There have been many changes in the EPF since its establishment in $1951 .^{38}$ One of the main issues relating to the effectiveness of the EPF is whether the quantum dividend provides adequate returns to contributors. The rate fluctuates according to the financial status of the EPF. However, it is generally felt that the EPF should generate income more effectively through careful and cautious investment management and strategy ${ }^{39}$, that is, pay a higher dividend and thereby enhance savings of contributors.

The other issue is low wages amongst a large segment of Malaysians. Household income surveys over the years, and more so since 1990, showed that the income growth of the top $20 \%$ of the population is in tandem with the national GDP growth. Nonetheless, the bottom $40 \%$ of households had the slowest growth with a mean income of $\mathrm{RM} 1,440$ in 2009. The low salary contributes to a small amount being deducted for savings under the EPF scheme [National Economic Advisory Council (NEAC) 2010]. The government has introduced a monthly minimum wage of RM900 for Peninsular Malaysia and RM800 for Sabah and Sarawak as proposed in the New Economic Model (NEM). ${ }^{40}$

37 Samad and Mansor, supra note 26 at p.147.

38 The EPF was established in 1951 in pursuant to the Employees Provident Fund Ordinance 1951. It became the EPF Act in 1982. The Act was again amended in 1991 which requires employees and their employers to contribute to their retirement savings, and allow workers to withdraw the savings on retirement or for social purposes before then.

39 Bakar, S.H.A. and F. Yunus, 'Social security policies in Malaysia: The Employees' Provident Fund (EPF) and Social Security Organization (SOCSO)', in Issues and Challenges of Social Policy East \& West, by R. Omar \& J. Dolling eds. (Kuala Lumpur: University of Malaya Press, 2000), pp. 187-219.

40 In line with the National Wages Consultative Council Act 2011 (Act 732), the government promulgated the Minimum Wages Order 2012 which was gazetted on July 16, 2012 and came into effect from January 1, 2013. 
In recent years, several EPF withdrawal proposals have been put forward. These include withdrawals to purchase a computer, for education, and to purchase cars, viewed as part of a plan to retire comfortably. However, it defeats the purpose of savings for old age as it reduces the amount of contribution/savings. ${ }^{41}$

\section{Social Security Organisation (SOCSO)}

SOCSO is responsible for ensuring the safety and welfare of workers in the private sectors. The available protection under SOCSO covers health and premature death or death. Nonetheless, the coverage is limited to private sector employees and, as such, civil servants, domestic workers, and the self-employed are thereby excluded. ${ }^{42}$

Two schemes are available under SOCSO: the employment injury scheme (EIS); and the invalidity pension scheme (IPS) that cover all eventualities and accidents of workers. Both the schemes have been made with a view to ensure cash benefits for workers and contributors in the event of any injury and/or accident. ${ }^{43}$

The EIS gives protection to workers in case of any accident, occupational disease, accident during employment and any emergency accident. In essence, the EIS covers accidents that take place at the workplace or with regard to the job. A number of schemes are available under the EIS such as temporary disablement benefits, permanent disablement benefits, dependent benefits, constant attendance allowance, funeral benefits and education loan. Similarly, IPS is a coverage scheme that caters for injuries, accidents and death or diseases that happen at the workplace but need not be work related. The available benefits under the IPS are invalidity pension benefits, invalidity benefits, survivor's pension scheme, constant attendance allowance, funeral benefits, rehabilitation benefits and education loan. ${ }^{44}$

${ }^{41}$ Samad, S. A. and S. Kaslam, 'Social and economic security. An overview of Malaysian system', 1st Terengganu International Business and Economics Conference, Kuala Terengganu, Malaysia, November 26-28, 2008.

42 Samad and Mansor, supra note 26 at p.147.

43 Mansor, N. and H. Awang, The Role of Social Safety Nets in Malaysia: Trends and Prospects towards Asia's Sustainable Development: The Role of Social Protection (France: Organization for Economic Co-operation and Development, 2002).

44 Samad and Mansor, supra note 26 at p.147. 


\section{Armed Forces Fund Board}

Like the EPF, the Armed Forces Fund requires monthly contributions by employees and employers of the armed forces. ${ }^{45}$ This fund has two schemes for its members. It is mandatory for serving members of the Armed Forces to contribute $10 \%$ of their monthly income while the government contributes $15 \%$ monthly. The second scheme is on a voluntary basis for officers in the Armed Forces including commissioned officers and mobilised members to contribute a minimum deduction of RM25, up to a maximum of RM750 per month with no contribution from the government. Among the benefits are a lump sum withdrawal inclusive of dividends and bonuses, death and disablement benefits scheme and partial withdrawal to purchase a house and a retraining programme for retiring and retired members. This scheme is more or less similar to the EPF regarding coverage and creates awareness among contributors to spend their savings wisely. ${ }^{46}$

\section{Private Retirement Scheme (PRS)}

The Malaysian government introduced this scheme to complement small EPF savings among the low income group in July 2012.This scheme has been designed to help salaried workers who are also EPF contributors and the self-employed to accumulate savings for retirement. Apart from the EPF savings, the PRS was approved by the Securities Commission and the Private Pension Administrator Act, ${ }^{47}$ the governing one-stop centre. A total of 24 funds are being offered by eight PRS providers comprising local and international financial institutions in Malaysia. ${ }^{48}$ Contributors are free to choose any fund and are allowed to contribute to more than one fund on the basis of affordability. ${ }^{49}$

45 Supra note 40.

46 Samad and Mansor, supra note 26 at p.149.

47 The Private Pension Administrator is a body approved under section 139C of the Capital Markets and Services Act 2007 to perform the function of record keeping, administration and customer service for members and contributors in relation to contributions made in respect of a private retirement scheme. All PRS applicants are required to open an account with the PPA and upon successful creation of the respective account, the PRS applicants are subsequently referred to as PPA members.

48 AM Investment Management, American International Assurance, CIMBPrincipal Asset management, Hwang Investment Management, ING Funds, Manulife Unit Trust, Public Mutual, \& RHB Investment Management.

49 Samad and Mansor, supra note 26 at p.150. 
This scheme works on the basis of the EPF principle that is, relying on contributions made by employees and employers. Two distinct accounts under the PRS termed as Account A and Account B are maintained. Account A contains $70 \%$ of the savings while the remaining $30 \%$ is in Account $\mathrm{B}$. Withdrawal from Account $\mathrm{A}$ is upon retirement while withdrawal from Account B is allowed once a year.

\section{Social Assistance Scheme}

The Malaysian government provides financial benefits known as Skim Bantuan Warga Tua (SBWT) or the Elderly Assistance Scheme for the elderly poor. ${ }^{50}$ This social assistance is provided by the Department of Social Welfare, under the Ministry of Women, Family and Community Development. ${ }^{51}$

The first scheme is cash benefits (bantuan orang tua). The amount of RM300 for old age assistance is given as financial aid to support them to enjoy a minimum standard of living in the community. To qualify, the elderly people must be very poor with no relative or kin and have no source of income support. This category also includes those with family members who are unable to provide support for the elderly. Another assistance provided under the Social Assistance Scheme by the Department of Social Welfare is 'shelter' known as the Seri Kenangan Home (Rumah Seri Kenangan or, RSK). RSK provides care, treatment and shelter to those aged 60 years and above who are not suffering from infectious diseases, have no relatives and are unable to care for themselves. ${ }^{52}$

\section{INADEQUACY OF SOCIAL PROTECTION}

The relevance of these schemes for the elderly people as a source of financial support through till the end may not be sufficient due to various reasons which are discussed below:

\section{Exclusive and not Inclusive}

What it means here is that all of the statutes targeted specific groups of people, the public sector for pensions, private sector and selfOng et. al, supra note 22 at p.147.

Samad and Kaslam, supra note 38.

52 Samad and Mansor, supra note 26 at p.143. 
employed for EPF and PRS, and employees for SOCSO. If the elderly does not fall within these specific target groups then he will not be protected. This approach has disadvantaged groups that do not receive its protection. For example, as long as a person is working, the various laws or statutes will be applicable to him. He will receive all kinds of benefits and protection. However, when he retires, there is no other specific statute that will cater for his needs. He becomes invisible. He is someone who is living under the radar of the legal framework. He will be visible again, once he falls within the group that needs assistance from the state.

This approach is more in line with social exclusion. Social exclusion has been defined as "the process through which individuals or groups are wholly or partially excluded from full participation in the society within which they live." ${ }^{\prime 3}$ It is a dynamic process through which disadvantaged individuals are excluded from essential resources like employment, health, education, social or political life, which ultimately perpetuates greater disadvantage and exclusion. ${ }^{54}$ The disadvantaged individuals cannot participate in the normal activities of the society or in activities that he or she would like to participate. ${ }^{55}$ Therefore the social exclusion may be viewed as a process caused by intersecting socio-economic and political agents that prevent certain groups from accessing resources and acquiring skills necessary to fully participate within the society. ${ }^{56}$

\section{Voluntary $v$ Mandatory}

While these schemes provide coverage for the formal sector, the provision is not mandatory for those in the informal sector, which is substantially large in Malaysia. For example, the EPF is extended to the self-employed on a voluntary contribution ${ }^{57}$ basis but the participation rate is relatively low. Although they are given a choice to make contributions toward their old age, most do not do so due perhaps to their financial needs and/or alternative ways

\footnotetext{
53 Nabin Rawal, Social Inclusion and Exclusion, 12 Dhaulagiri Journal of Sociology and Anthropology, 163 (2008).

54 International Federation on Aging, Social Inclusion for an Aging Population, Country Summary Report, 2010, p.4.

55 Ibid.

56 Ibid.

57 See, section 43(8) of the Employee Provident Fund Act 1991.
} 
of utilising funds. Workers in the informal sector where retirement does not apply will usually work until they are unable to do so due to ill health. Even if those from the informal sector contribute to $\mathrm{EPF}$, the returns are arguably lower as it is without the employer's contribution. They literally have no choice except recourse to their personal savings (if any). ${ }^{58}$

The EPF is inadequate if it is the only source of income..$^{59}$ In fact, it has been argued that the EPF is not 'fit for purpose'. Rising costs associated with longer life expectancy and the effect of inflation diminishes the size of savings.$^{60}$ This coupled with the regulations to which the EPF is subject to results in the EPF being an inadequate recourse.

\section{Employment Related}

Besides pensions and the EPF, SOCSO does not have any impact on the elderly since it is only relevant as long as a person is working. Once the person retires, SOCSO will no longer be relevant. The fact is that the premium paid to SOCSO will not be returned once a person retires even though he/she never made any claim when working. Therefore, in that sense SOCSO does not provide any benefit for the elderly.

It is important to ensure that all Malaysians are covered by social protection and are able to sustain an acceptable standard of living throughout their lives. Social protection is an important platform during an economic crisis and for vulnerable groups. ${ }^{61}$ However, only certain groups of people are covered under the social protection programme and these include all private sector employees regardless

Fon Sim Ong F,'Ageing in Malaysia: National policy and future direction', (Kuala Lumpur: Faculty of Business and Accountancy, 2001) https://www. google.com/\#q=Ageing+in+Malaysia:+National+policy+and+future+direction (Last visited on July 3, 2015).

59 Kong See Hoh, 'EPF Savings of Many Retirees Inadequate', The Sun, August 22, 2012) http://www.mef.org.my/library/MC_MEFinthenews/Sun120822a. pdf (Last visited on July 3, 2015).

60 Caraher Kevin, 'Global Forces, Institutional Pressures: The Malaysian Employees Provident Fund in need of Reform' (2007), http://etheses.dur. ac.uk/2419/1/2419_430.pdf?UkUDh:CyT (Last visited on July 3, 2015).

${ }_{61}$ National Economic Advisory Council (NEAC). 2010. New Economic Model for Malaysia. Putrajaya: NEAC, Malaysia. 
of their status, public sector employees who opted for the EPF scheme (instead of pension scheme) and those who have yet to be confirmed in the service and also formally employed employees. In 2008, EPF introduced an initiative to allow self-employed persons to contribute to the EPF scheme. However, the response to this initiative was weak as the income of the self-employed is uncertain and unstable. Hence, the informal sector is still excluded from this scheme. ${ }^{62}$

\section{SOCIAL PROTECTION SCHEMES IN THE PHILIPPINES}

There are four tiers of old age system of protection in the Philippines, with the first tier being in the form of a social assistance scheme, where different departments of government implement various social assistance programmes for the benefit of the poor and elderly - including the Monthly Social Pension afforded to all indigent senior citizens under the Expanded Senior Citizens Act 2010 (RA 9994). The second tier is the mandatory defined-benefit tier, with schemes provided for and maintained by the Social Security System (SSS) for private sector employees, and the Government Service and Insurance System (GSIS) for public sector employees. The third tier of the available system is the mandatory defined-contribution tier maintained under the Pag-IBIG Fund. The fourth tier is a voluntary tier consisting of supplementary personal pension schemes bought by individuals.

\section{Social Security System (SSS)}

The SSS covers private sector workers (including self-employed persons); and includes benefits such as death, disability, sickness, maternity, loans, and of course, retirement. ${ }^{63}$ Retirement benefit is given in cash either in the form of monthly pension or lump sum paid to a member who can no longer work due to old age.$^{64} \mathrm{The}$ amount of

62 Samad and Mansor, supra note 26 at p. 148.

63 Josefina N. Natividad, 'Ageing in the Philippines: An overview', in Ageing in the Asia-Pacific region: Issues, policies and future trends, by David R. Phillips ed. (Routledge: London \& New York, 2000), p.274.

64 'Retirement Benefits' (Republic of the Philippines Social Security System) $\mathrm{http}: / /$ www.sss.gov.ph/sss/index2.jsp?secid=73\&cat=4\&pg=null (Last visited on July 3, 2015). 
pension afforded to each member is governed by the Social Security Act 1997 (RA 8282). A member who may qualify for such benefit is one who is 60 years old, separated from employment or has ceased to be self-employed, and has paid at least P120 monthly contributions prior to the semester of retirement; or a member who is 65 years old, whether employed or not, and has paid at least P120 monthly contributions prior to the semester of retirement. ${ }^{65}$

The monthly pension is a lifetime cash benefit paid to a retiree who has made at least P120 monthly contributions prior to his retirement; while the lump sum amount is granted to a retiree who has not paid the required P120 monthly contributions - the lump sum amount is equal to the total contributions paid by the member and by the employer, including the interest. ${ }^{66}$

The amount of contributions is fixed at $3.33 \%$ of an employee's monthly salary, while employers pay $7.07 \%$ as required by law. ${ }^{67}$ However, the percentage of contribution was increased in June 2013 to a proposed $7.37 \%$ by employers and $3.63 \%$ by employees; to be complemented accordingly by a corresponding increase in benefits. $^{68}$

The amount of monthly pension which a retiree receives depends on the amount of contributions, including the credited years of service (CYS) and the number of dependent minor children (not exceeding five).

The Social Security Act, 1997 amended in February 2013, has increased the amount of minimum monthly pension received by members to P1,700 if they have at least 10 CYS but less than 20; while those with at least $20 \mathrm{CYS}$ will receive a minimum of P3,400. Three years after the implementation of the amendment Act, the said amounts shall be increased by at least P500 for those with 10 CYS

\footnotetext{
65 Ibid.

66 Ibid.

67 'New SSS Contribution Schedule' (Philippine Social Security System) http:// www.sss.gov.ph/sss/printversion.jsp?id=111\&file=regi_contrib_table.html (Last visited on July 3, 2015).

68 E Umbao, 'SSS Contribution Hike Might be Issued in June 2013' (Philippine News, July 3, 2013) http://philnews.ph/2013/05/02/sss-contribution-hikemight-be-issued-in-june-2013/ (Last visited on July 3, 2015).
} 
and P1,000 for members with at least $20 \mathrm{CYS} .{ }^{69}$ This move is clearly in line with Article XVI, Section 8 of the Philippine Constitution, which stipulates that pension systems will be periodically reviewed and upgraded. ${ }^{70}$

\section{Government Service and Insurance System (GSIS)}

The GSIS is a social security agency for government employees, which covers several essential services including social security benefits and general insurance. ${ }^{71}$ The retirement benefit system is a mandatory system for all government employees.

For the purpose of retirement benefits, the contribution rate towards retirement fund is $7 \%$ by the employee, and $10 \%$ by the employer (government), ${ }^{72}$ a significantly higher percentage compared to the SSS program. A member is eligible for retirement benefit under the Republic Act No.8291 73 when he/she has satisfied the following conditions: he/she has rendered at least 15 years of service; he/ she is at least 60 years of age at the time of retirement and; he/ she is not receiving a monthly pension benefit from permanent total disability. ${ }^{74}$

There are two options for retirees: the retiree may get his five years' worth of pension (60 months x Basic Monthly Pension or, BMP) in a lump sum in advance, and receive the monthly pension starting at the end of the five year guarantee period; or the retiree may opt to receive a cash payment upon retirement which is equivalent to 18 months of BMP and then receive a monthly pension for life starting immediately upon retirement. ${ }^{75}$

69 J.P. Manalastas, 'SSS Pension Hike Okayed' (Journal Online, 3 February 2013) http://www.journal.com.ph/index.php/news/national/44136-sss-pension-hikeokayed ( Last visited on July 3, 2015).

70 Section 8 of Article XVI of the Philippines Constitution 1987 states that "The State shall, from time to time, review to increase the pensions and other benefits due to retirees of both the government and the private sectors."

71 'The GSIS' (Government Service Insurance System) http://www.gsis.gov.ph/ default.php?type=main\&id=28 (Last visited on July 3, 2015).

72 'Premium Payments' (Government Service Insurance System) http://www.gsis. gov.ph/default.php?id=86 (Last visited on July 2, 2015).

73 The Republic Act No.8291 otherwise known as the Government Service Insurance System Act of 1997 came into force on May 30, 1997.

74 Retirement under RA 8291' (Government Service Insurance System) http:// www.gsis.gov.ph/default.php?id=33 (Last visited on July 2, 2015).

75 Ibid. 
Effective from January 2013, the new minimum basic pension of P5,000 has been implemented for all GSIS pensioners receiving less than P5,000 monthly, while those receiving between P5,000 and P8,000 will receive a P200 increment monthly. ${ }^{76}$ This increase is in response to the needs of old age in light of the rising prices of basic commodities. ${ }^{77}$

\section{Pag-IBIG Fund}

The Pag-IBIG Fund, also known as the Home Development Mutual Fund (HDMF), is a national initiative to answer the need for a national savings programme and an affordable shelter financing scheme. ${ }^{78}$ While membership used to be voluntary, the implementation of the Republic Act 9679 in 2008 made membership to the fund mandatory for all members of the GSIS and SSS. ${ }^{79}$

The mandatory monthly contribution by employees is $1 \%$ (for those whose monthly earnings are P1,500 and below) or $2 \%$ (for those earning above $\mathrm{P}, 1500$ ); while the share to be paid by employers is fixed at $2 \%$. Note that the maximum monthly earnings used in calculating employee contributions is set at P5,000 meaning that the maximum monthly contribution by both the member and the employer counterpart is $\mathrm{P} 100 .^{80}$ While this amount may seem minimal, it must be taken into consideration that this Fund is one that supplements the existing SSS or GSIS scheme.

The Fund guarantees the refund of the member's total accumulated savings (TAV), which consists of the member's accumulated contributions, the employer counterpart contributions (if any), and the dividend earnings which have been credited to the member's account. ${ }^{81}$ Members shall be compulsorily retired upon reaching the

76 'GSIS Pensioners Receive Hike in 2013' (Government Service Insurance System) http://www.gsis.gov.ph/news.php?id=318 (Last visited on July 2, 2015).

77 'PNoy OKs Hike of GSIS Minimum Pension to 5k' (Government Service Insurance System) http://www.gsis.gov.ph/news.php?id=288 (Last visited on July 2, 2015).

78 'History of Home Development Mutual Fund' (HDMF Official Site) http:// www.pagibigfund.gov.ph/abouthdmf.aspx (Last visited July 20, 2015).

79 'FAQ' (HDMF Official Site) http://www.pagibigfund.gov.ph/faq/FAQ.htm (Last visited on July 20, 2015).

80 Ibid.

81 'Provident Savings Benefit Claim' (HDMF Official Site) http://www. 
age of 65. They may also opt to retire upon the occurrence of any of the following: (i) Actual retirement from the SSS, the GSIS or a separate employer provident/retirement plan, provided the member has at least reached the age of 45; or (ii) Upon reaching the age of $60 .{ }^{82}$

\section{Private Pension Schemes}

The passing of the Republic Act No. 7641 has provided for mandated payment of retirement benefits. ${ }^{83}$ All private sector employees regardless of their position, designation or status and irrespective of the method by which their wages are paid are entitled to retirement benefits upon compulsory retirement at the age of 65 or upon optional retirement at 60 or more but not at 65 . The minimum retirement

pay due to employees shall be equivalent to one-half of the monthly salary for every year of service, a fraction of at least six months being considered as one whole year. The benefits under this law include other than those granted by the Social Security System. Any employee may retire or be retired by his employer upon reaching the retirement age established in the Collective Bargaining Agreement (CBA) or other applicable employment contract and shall receive the retirement benefits granted therein. However, such retirement benefits shall not be less than the retirement pay required by RA 7641 and if such retirement benefits under the agreement are less, the employer is required to pay the difference..$^{84}$

Voluntary personal pension funds are offered by pre-need and life insurance companies. Pre-need companies are plan issuers authorised under Republic Act No. 8799 (the Securities Regulation Code $)^{85}$ to sell or offer for sale to the public any pre-need plan in accordance with rules and regulations which the Securities and Exchange Commission has prescribed. Pre-need plans pertain to

pagibigfund.gov.ph/benproprovident.aspx (Last visited on July 13, 2016).

82 Ibid.

83 The Republic Act No. 7641 (Mandatory Retirement Pay Law) was enacted in 1992 and came into effect on December 9, 1992.

84 Emilio B. Aquino, Private Pension Schemes in the Philippines: Regulatory Practices, Conference on Private Pensions in Asia, October 24-25, 2002 in Seoul, Korea, p.2.

85 The Republic Act No. 8799 (the Securities Regulation Code) was enacted in 2000 and came into force on August 8, 2000. 
contracts which provide for the performance of future services or the payment of future monetary considerations at the time of actual need, for which the plan holders pay in cash or instalments at stated prices, with or without interest or insurance coverage and includes pension plans. Other dominant plan types are life, education and interment plans.

On the other hand, the Philippine Insurance Code 4 allows insurance companies to offer endowment and annuity contracts which are classified as life insurance contracts for purposes of the law. Old age and regular endowments avail those who want guaranteed retirement income without, however, entirely losing the protection element of the plans. ${ }^{86}$

\section{INADEQUACY OF SOCIAL PROTECTION IN THE PHILIPPINES}

Like Malaysia, there are some problems in the social protection schemes in the Philippines which are as follows:

\section{Exclusive not Inclusive}

Apart from the insurance programmes that appear as market goods covering at least those who have the capacity for shouldering the premium, the social protection programmes exclude a number of vulnerable groups, like the elderly. There are also other programmes that cater to risk mitigation demands of other vulnerable groups. The localised nature of social protection policies thus requires the creation of a separate programme for each of the vulnerable groups.

\section{Not Beneficial}

Insurance programmes, in particular, provide a miniscule amount of benefits to its members. Thus, services become less meaningful to members, especially since the value of these services fail to adjust to inflation. Sta. Ana relates this observation in health insurance policies that cover a very limited amount of medical care expenses, and pension payments to retirees. ${ }^{87}$

\footnotetext{
86 Private Pension Schemes in the Philippines: Regulatory Practices, http:// www.oecd.org/finance/private-pensions/2763673.pdf (Last visited on June 22, 2015).

87 Sta. Ana, F., 'Briefing Paper: Social Protection in the Philippines.' Paper
} 


\section{Problems in Implementation}

Moreover, there are some problems in the implementation of social protection schemes in the Philippines ${ }^{88}$ For example, appointments in the Philippine bureaucracy especially in filling executive positions are often driven by political motives. Some appointments are part of the political reward system and in these cases the appointments also strengthen the control of the government over the operations of the bureaucracy. The shifting of accountability of implementing agencies from the general public to the government of the day creates a moral hazard. For instance, the problem with politics becoming involved in the implementation of public policies is that the inclusive nature of these policies, especially social protection programmes, may be disregarded so that only few would benefit from them.

In the Philippines, social protection schemes are scattered across various government agencies. Moreover, each social protection programme appears as a stand-alone policy that lacks synergy with the general development plan. For instance, in creating employment opportunities, the investment climate of a country, and all its aspects, must also be given sufficient attention since jobs would mainly be generated by private investments. The effectiveness of social protection in reducing poverty is also a function of its synchronicity with development plans and thus merits consideration. ${ }^{89}$

\section{ROLE OF SOCIAL PROTECTION}

Poverty and consequently the lack of financial security is one of the key problems that the elderly people face almost all over the world. ${ }^{90}$ The proportion of the elderly in poverty is higher than in

presented at the United Nations Development Programme inter-regional workshop entitled, Social Protection in an Insecure Era: A South-South Exchange on Alternative Policy Responses to Globalization, Santiago de Chile, May 2002.

88 A.T. Cruz, 'Portability of Benefit Rights in Response to External and Internal Mobility: The Philippine Experience.' (13th Regional Conference for Asia and the Pacific, Kuwait, 2004).

89 Social Protection in the Philippines: A Case Study on the country's social security model and conditional cash transfer program, Global Network, http:// www.solidar.org/IMG/pdf/d4_philippines-social_protection_final.pdf (Last visited on June 29, 2015).

90 Ghazy Mujahid, Joseph Pannirselvam, and Brooks Doge, The Impact of Social 
the working age population, indicating the increasing likelihood of people falling into poverty as they leave the workforce. Therefore, one way of addressing poverty among the elderly is through social protection. The social protection schemes for the elderly encompass a variety of measures to reduce vulnerability and to improve income security in later life. Generally, the social protection measures are designed for improving the well-being of the elderly. ${ }^{91}$

Social protection is often mentioned as a likely contributor to the decline in elderly poverty. In fact, there is a striking association between the rise of social protection and the decline in elderly poverty. ${ }^{92}$ Social protection not only reduces poverty, but also provides households with security to invest in children's and grandchildren's education and health, as well as releases resources to invest in income-generating activities. ${ }^{93}$ The existing literature demonstrates that the elderly receiving social protection are more than those not receiving, feel their basic needs are being met, are able to support household activities, and have an overall improved outlook on life. ${ }^{94}$ The elderly can utilise the money they receive through social protection schemes for household expenses (shelter, food and amenities), health needs, cultural and religious activities, investment in productive activities and for savings.

Mujahid and Pannirselvam found in their study that the pensions as a social protection scheme, given the small amount a recipient received, were reportedly insufficient but viewed in a positive light. Some of the elderly and local officials reported that even though the pension amount was not sufficient to meet all the needs of the elderly, they realised that it was keeping them out of extreme poverty ${ }^{95}$ Due to the social protection schemes, the elderly felt more independent,

Pensions: Perceptions of Asian Older Persons, UNFPA, 2008, p.18

91 Ibid.

92 Social Security and Elderly Poverty, The National Bureau of Economic Research, http://www.nber.org/bah/summer04/w10466.html (Last visited on July 3, 2015).

93 Mujahid and Pannirselvam, supra note 90 at p.18.

94 Ibid; See also, International Labour Organisation, Social Protection for Older Persons: Key Policy Trends and Statistics, Social Protection Policy Papers, 2014, P.1.

95 Ibid; See also, Bertil Videt, Social Protection for Inclusive Growth, The Broker, January 16, 2014 http://www.thebrokeronline.eu/Articles/Social-protectionfor-inclusive-growth (Last visited on 18 July, 2018). 
proud, useful, and more secure. In addition, such schemes provided the elderly with greater self-esteem and confidence. For the lonely elderly with disabilities, the social protection gave them strength, enhanced their living standards, reduced complexity in society, and promoted community integration and participation in local cultural events. For the poor elderly, the social protection provided a better quality of life. The research revealed that even a small, regular amount of pension provided a sense of security that promoted the overall wellbeing of disadvantaged elderly people. ${ }^{96}$ Most importantly, social protection schemes have been instrumental in reducing neglect and abuse of older persons by their family members as they have some money to contribute to the family income. It is widely known that

the elderly could experience economic and psychological pressures if they have no money.

The elderly value highly the social protection schemes in terms of meeting their basic necessities and household expenses, accessing health care and improving their overall well-being. These regular amounts of income provide the elderly not only with added financial security, but also allow them increased participation in community life, in addition to enhancing their self-esteem and dignity in old age. ${ }^{97}$ Thus, without social protection there is a strong possibility that the elderly would be in poverty which has been reflected in a research in some developed countries. ${ }^{98}$ Needless to say, social protection schemes provide a base of income protection for the elderly and these schemes are more likely to keep the elders out of poverty. ${ }^{99}$ As such, the various social protection schemes, even those providing a small bit of assistance, can go a long way in reducing poverty.$^{100}$ Alongside reducing poverty, the social protection schemes can help the elderly gain access to health care, and enhance their status and social standing. ${ }^{101}$

96 Sri Wening Handayani and Babken Babajanian (eds.), Social Protections for Older Persons: Social Pensions in Asia, 2012, Asian Development Bank, Manila, Philippines, pp.2-3.

97 Mujahid and Pannirselvam, supra note 90 at p.18.

98 Kebin Wu, How Social Security Keeps Older Persons Out of Poverty across Developed Countries, Luxembourg Income Study Working Paper Series, Working Paper No. 410, 2005.

99 Ibid.

100 Social Pensions Key to Protecting Elderly, Reducing Poverty, July 2012, http:// www.adb.org/news/social-pensions-key-protecting-elderly-reducing-poverty (Last visited on July 6, 2015).

${ }^{101}$ Ibid. 


\section{CONCLUSION}

Social protection schemes have been developing for half a century in Malaysia and the Philippines. Despite this, the coverage remains restricted to a small proportion of the elderly. One of the main challenges faced by the elderly in these countries is the inadequacy of their savings upon retirement. Generally, Malaysians have very limited savings, especially the $40 \%$ with a very low average household income. ${ }^{102}$ Additionally, Malaysians currently live longer, 71.97 years for males and $77.73^{103}$ years for females, which is ten

years longer than four decades ago (65 years in 1973). Therefore, it is important to prepare them for a sustainable quality of life, and to ensure that they are financially and economically independent. This would include being able to afford healthcare cost, an obvious important requirement given their age.

Presently, the social protection in Malaysia is manifested through the National Social Policy for public assistance. ${ }^{104}$ Protection for the elderly, the disabled, the poor, and the vulnerable women are also covered under this policy. The National Policy for the Elderly is limited with no clear mechanism and coordination for implementation. The policy established by the Department of Social Welfare provides protection and assistance for the elderly, which includes benefits in cash and kind. However, this policy needs to be reassessed according to the index of benefits and socio-economic changes. Both the definition and mechanism to identify the eligible elderly have to be strengthened. The policy must also reflect the adequacy of in cash or in kind benefits provided for the elderly as well as the resiliency of the elderly in their golden years. It must also consider the role played by the private sector to enable capable pensioners to serve in the job market. ${ }^{105}$

On the other hand, despite facing some problems (at least in implementation), the social protection schemes in the Philippines are considered as wide enough in ensuring the well-being of the

\footnotetext{
102 See above n 23, p.140. In 2009, the average household income was RM1,440 according to the $10^{\text {th }}$ Malaysia Plan.

103 http://www.geoba.se/country.php?cc=MY\&year=2015 (Last visited on June $23,2015)$.

104 The National Social Policy was adopted in August 2003.

105 Samad and Mansor, supra note 26 at p.154.
} 
elderly. ${ }^{106}$ Moreover, to provide additional benefits and protection for the elderly, the government of the Philippines enacted the Expanded Senior Citizens Act in 2010. ${ }^{107}$ Under this Act, the government is obliged to extend assistance to the elderly in various forms, with one being a social pension for indigent senior citizens. ${ }^{108}$ In a similar vein, it is proposed that Malaysia should also come up with such legislation in order to provide more benefits to the elderly.

\section{REFERENCES}

Asian Development Bank, Social Protection, 2003, p.1.

Cruz, A. T. (2004). 'Portability of benefit rights in response to external and internal mobility: The Philippine experience.' (13th Regional Conference for Asia and the Pacific, Kuwait, 2004).

Bakar, S. H. A., \& Yunus, F. (2000). 'Social security policies in Malaysia: The Employees' Provident Fund (EPF) and Social Security Organization (SOCSO)', in Issues and Challenges of Social Policy East \& West, by R. Omar \& J. Dolling eds. (Kuala Lumpur: University of Malaya Press, 2000), pp. 187219.

Videt, B. (2014). Social protection for inclusive growth, The Broker, January 16, 2014. Retrieved from http://www.thebrokeronline. $\mathrm{eu} /$ Articles/Social-protection-for-inclusive-growth

Caraher, K. (2007). 'Global forces, institutional pressures: The Malaysian Employees Provident Fund in need of reform'. Retrieved from http://etheses.dur.ac.uk/2419/1/2419_430. pdf?UkUDh:CyT

David, E. B, Emmanuel J., \& Larry, R. (2011). Social protection of older people. (Working Paper Series, 2011). Program on the Global Demography of Aging, p.1.

106 Sta. Ana, supra note 82.

107 This Act is an extension of the Senior Citizens Act 1992. It shows a clear effort on the part of the Philippines Government to embody the spirit of their Constitution, which is to provide adequate support for their people - especially for groups who are underprivileged, or require more attention, such as the elderly.

108 Section 5(h)(1) of the Expanded Senior Citizen Act 2010 provides "Indigent senior citizens shall be entitled to a monthly stipend amounting to 500 pesos (Php500.00) to augment daily subsistence and other medical needs of senior citizens, subject to a review every two (2) years by Congress, in consultation with the [Department of Social Welfare and Development]" 
Devereux, S., \& R. Sabates-Wheeler. (2004). Transformative Social Protection. Vol. 232. University of Sussex, Institute of Development Studies, p.10.

Emilio B. Aquino. (2002). Private Pension Schemes in the Philippines: Regulatory Practices, Conference on Private Pensions in Asia, October 24-25, 2002 in Seoul, Korea, p.2.

E Umbao. (2013). SSS Contribution Hike Might be Issued in June 2013 (Philippine News, July 3, 2013) http://philnews. $\mathrm{ph} / 2013 / 05 / 02 /$ sss-contribution-hike-might-be-issued-injune-2013/

Ong, F. S., Phillips, D. R., \& Hamid, T. A. (2009). Ageing in Malaysia: Progress and prospects. In T.-h. Fu \& R. Hughes (Eds.), Ageing in East Asia: Challenges and policies for the twenty-first century (pp. 145). London: Routledge.

Mujahid, G., Pannirselvam J., Doge, B. (2008). The Impact of Social Pensions: Perceptions of Asian Older Persons, UNFPA, p.18.

Standing, G. (2007). Social Protection. Development in Practice, 17:4-5, 511-522, https://doi.org/10.1080/09614520701469435

HelpAge International, Ageing population in the Philippines, http:// ageingasia.org/ageing-population-philippines1/ (Last visited on June 29, 2015).

HelpAge International, Strengthening Older People's Rights: Towards a UN Convention (2010), p.5.

Spitzer, H., Rwegoshora, H., \& Mabeyo, Z. M. (2009). The (missing) social protection for older people in Tanzania. Final report. Institute of Social Work, Tanzania.

International Labour Organisation. (2014). Social protection for older persons: key policy trends and statistics. Social Protection Policy Papers.

Josefina, N. N. (2000). Ageing in the Philippines: An overview, in Ageing in the Asia-Pacific region: Issues, policies and future trends, by David R. Phillips ed. (Routledge: London \& New York), p.274.

Manalastas, J. P. (2013). SSS pension hike okayed (Journal Online, 3 February 2013). Retrieved from http://www.journal.com. $\mathrm{ph} /$ index.php/news/national/44136-sss-pension-hike-okayed

Kebin Wu. (2005). How social security keeps older persons out of poverty across developed countries, Luxembourg Income Study Working Paper Series, Working Paper No. 410.

Mansor, N., T.E. Chye, A. Boerhanoeddin, F. Said \& S.M. Said. (2001). Malaysia: Protecting workers and fostering growth, in 
East Asian Labor Markets and the Economic Crisis: Impacts Responses and Lessons, by G. Betcherman \& R. Islam eds. (United States of America: World Bank Publications), pp.141194.

Mansor, N., \& H. Awang. (2002). The Role of Social Safety Nets in Malaysia: Trends and Prospects towards Asia's Sustainable Development: The Role of Social Protection (France: Organization for Economic Co-operation and Development, 2002).

Nabin Rawal. (2008). Social inclusion and exclusion, 12 Dhaulagiri Journal of Sociology and Anthropology, 163.

National Economic Advisory Council (NEAC). (2010). New Economic Model for Malaysia. Putrajaya: NEAC, Malaysia.

New SSS Contribution Schedule' (Philippine Social Security System). (2015). Retrived from http://www.sss.gov.ph/sss/ printversion.jsp?id $=111 \&$ file $=$ regi_contrib_table.html

Philomena M. M., \& Elosy K. M. (2012). Social protection for the elderly as a development strategy: A case study of Kenya's old persons cash transfer programme', III IESE CONFERENCE Mozambique: Accumulation and Transformation in a context of International crisis, 4-5 September 2012.

Holzmann, R., \& Jorgensen, S. (2000). Social risk management: A new conceptual framework for social protection and beyond, Social Protection Discussion Paper No. 0006, World Bank, February 2000, p.3.

Sanchez, N. K. (2008). The Filipino Senior Citizen: At a Glance' ISA RC11 Sociology of Aging 4.

Siti Zaharah Jamaluddin., Gan Ching Chuang., \& Mohammad Abu Taher. (2015). Strategies in the prevention or reduction of elder abuse in Bangladesh and Malaysia. Procedia-Social and Behavioral Sciences, 43, 172

Samad, S. A., \& Norma Mansor. (2013). Population ageing and social protection in Malaysia, 50 (2) Malaysian Journal of Economic Studies, 144.

Sanyal, A., \& Singh, C. (2013). Universal Pension Scheme in India 420 IIM Bangalore Research Paper, p.4.

Samad, S. A., \& S. Kaslam. (2008). Social and economic security. An overview of Malaysian system', 1st Terengganu International Business and Economics Conference, Kuala Terengganu, Malaysia, November 26-28. 